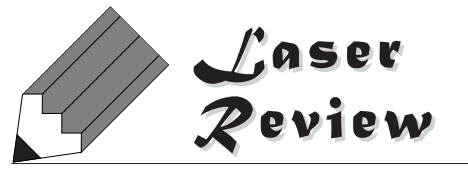

$$
\text { 光ヘッド用モノリシック2波長レーザー }
$$

油利 正昭, 今藤修*, 小林 康宏*, 福久敏哉*, 大西俊一,

持田 篤範, 伊藤 国雄 $*$, 清水裕一

松下電器産業(株) 半導体社 半導体デバイス研究センター ( ₹569-1193 大阪府高槻市幸町1-1)

*松下電器産業(株) 半導体社 ディスクリート事業部 (テ617-8520 京都府長岡京市神足焼町1)

\section{Monolithically-Integrated Dual-Wavelength Laser Diodes for Optical Pickups}

\author{
Masaaki YURI, Osamu IMAFUJI,* Yasuhiro KOBAYASHI,* Toshiya FUKUHISA,* \\ Toshikazu OHNISHI, Atsunori MOCHIDA, Kunio ITOH,* and Hirokazu SHIMIZU \\ Semiconductor Devices Research Center, Semiconductor Company, Matsushita Electric Industrial Co., Ltd. \\ 1-1, Saiwai-cho, Takatsuki, Osaka 569-1193 \\ *Discrete Device Division, Semiconductor Company, Matsushita Electric Industrial Co., Ltd. \\ 1, Kotari-Yakemachi, Nagaokakyo, Kyoto 617-8520
}

(Received August 13, 2001)

\begin{abstract}
$780 \mathrm{~nm}$-band $\mathrm{AlGaAs}$ and $650 \mathrm{~nm}$-band AlGaInP laser diodes are monolithically integrated on a GaAs substrate as the light source in DVD/CD optical pickups. In order to reduce internal losses for improved characteristics and to ensure better flexibility of device design, real-refractive index-guided self-aligned (RISA) structure is employed for both $780 \mathrm{~nm}$ and $650 \mathrm{~nm}$-band LDs. As a result, low noise characteristics due to selfsustained pulsation in the both wavelength bands have been achieved. A dual-wavelength laser with a high power ( > $100 \mathrm{~mW}$ ) $780 \mathrm{~nm}$-band LD has also been developed for recording of CD-R/RW disks.
\end{abstract}

Key Words: Real refractive-index-guided self-aligned structure, Self-sustained pulsation, DVD, CD-R, CD-RW

1.はじめに

近年DVDシステムは, ビデオプレーヤ,パソコン,カーナ ビゲーションシステム等の分野で,急速に普及している. これらDVDシステムにおいては, DVDの再生はもちろんの こと, $\mathrm{CD}, \mathrm{CD}-\mathrm{R}, \mathrm{CD}-\mathrm{RW}$ 等 $\mathrm{CD}$ 系の従来ディスクも再生で きる必要がある。しかしながらCD系ディスクの中で, 近年 普及の著しいCD-Rデイスクはその記憶材料に波長選択性 の強い有機色素を用いているために, DVD用の $650 \mathrm{~nm}$ 帯半 導体レーザーでは再生することができない.このため, 一 般にDVDシステムの光ヘッドには, $650 \mathrm{~nm}$ 帯半導体レー ザーに加え780 nm帯半導体レーザーが併用されている. この結果, 光学部品点数が増え, 光へッドの小型・軽量化 さらにはコストダウンの妨げとなっていた。このような 背景から,一つの半導体レーザーパッケージから $650 \mathrm{~nm}$ 帯 赤色レーザー光と $780 \mathrm{~nm}$ 帯赤外レーザー光の両方を出射 することのできる2波長レーザーの開発が盛んに行われ,一 部実用化されるに至っている1-5).

2波長レーザーを実現する方法には，2個の半導体レー ザーチップを一つのサブマウント上に実装する「ハイブ
リッド方式」と, 同一の半導体基板上に $650 \mathrm{~nm}$ 帯と780 nm 帯の半導体レーザーを作り込む「モノリシック方式」の2種 類がある。2波長レーザーを用いた光へッドにおいては, $650 \mathrm{~nm}$ 帯と780 nm帯のレーザー光が一つの光学系を共有 するために, それぞれの発光点間の距離(以下, 発光点間隔) が光学設計上重要なパラメータとなる.この発光点間隔 は一般には100〜300 $\mu \mathrm{m}$ の間で選ばれるが, $\pm 1 \mu \mathrm{m}$ 程度の 絶対精度が要求されることが多い。このような観点から, 発光点間隔がフォトリソグラフィー工程によって容易に 制御できるモノリシック型の方が有利であると考えられ る.

一方, 個々のレーザーの性能に関しては, 戻り光誘起雑 音を低減するために用いられる高周波重畳回路を不要と して, さらに部品点数を減らすために自励発振型 2 波長レー ザーへの要望が高まっている，さらには, 再生専用のみな らず, 記録にも対応した高出力 2 波長レーザーへの要望も高 まりつつある。

以上のような背景から, 我々は自励発振や高出力動作へ の展開が容易な導波路構造として実屈折率導波 (Real-refractive Index-guided Self-aligned; RISA) 構造を650 nm帯と 
$780 \mathrm{~nm}$ 帯の両方に採用したモノリシック2波長レーザーの 開発に取り組んできた。本報告では, 実屈折率導波型 2 波長 レーザーの基本構造と作製プロセスを示した後, 本構造を 採用した自励発振型 2 波長レーザー, さらには $100 \mathrm{~mW}$ 級の 高出力赤外レーザーを搭載したCD-R/RW記録対応型2波長 レーザーについて述べる。

\section{2. 実屈折率導波型2波長レーザー}

\section{1 実屈折率導波構造}

まず, 実屈折率導波 (Real-refractive Index-guided Selfaligned; RISA) 型半導体レーザー6)について AlGaAs系赤外 半導体レーザーを例に説明する。

Fig. 1 (a)に従来の損失導波型レーザーの断面構造を示 す7).この構造では, 電流ブロック層として GaAsが用いら れているが, GaAsの禁制帯幅は発振波長のエネルギーより も小さいので大きな光吸収を生じる。このため,レーザー 光はブロック層部分にあまりしみだすことが出来ず, スト ライプ中央部に閉じ达められる。適当なストライプ幅の もとでは,この光閉じ込め効果により, 単一モード発振が できる。

これに対し, Fig. 1(b)に示すように, 電流ブロック層を

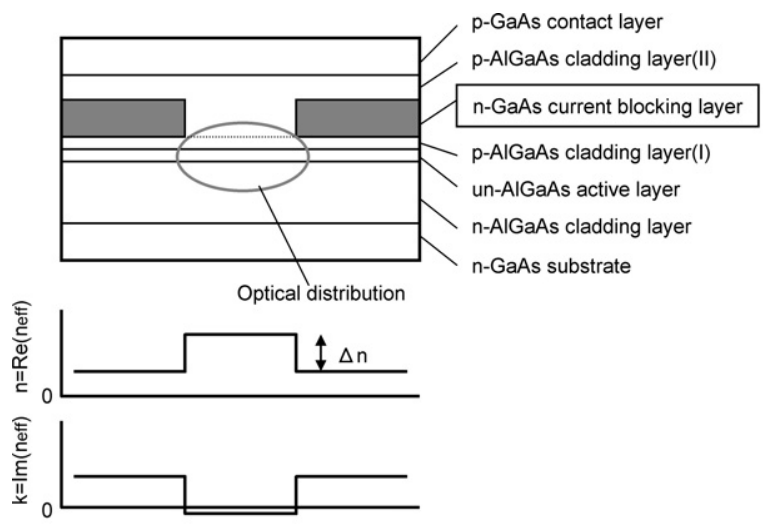

(a)
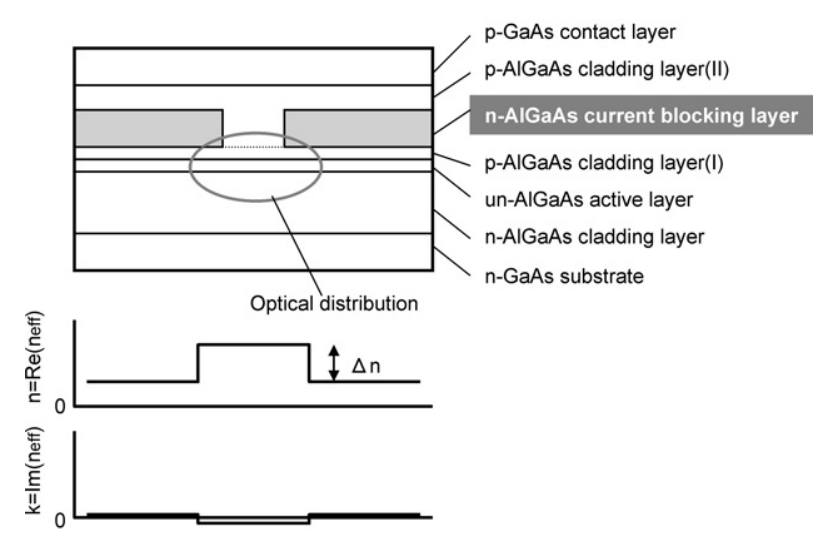

(b)

Fig. 1 Schematic drawings of laser structure and corresponding profile of effective refractive index for (a) complex refractive index-guided structure and (b) real refractive index-guided structure, respectively.
発振波長に対して透明な材料, すなわち $\mathrm{AlGaAs}$ で構成した 構造が, 実屈折率導波構造である ${ }^{8)}$ 。この構造では, レー ザー光が電流ブロック層でほとんど吸収されない。しか も, 電流ブロック層の屈折率を第 $2 \mathrm{p}$ クラッド層(埋め込みク ラッド層)の屈折率よりも小さくすることで, 水平方向に実 屈折率ステップ $\Delta n$ が形成され, これにより水平方向の光閉 じ込めが行われる。なお, $\mathrm{AlGaInP}$ 系赤色半導体レーザー の場合は, 電流ブロック層として $650 \mathrm{~nm}$ の発振波長に対し て透明なAlInPを用いることで, 同様の実屈折率導波構造を 構成することが出来る9).

従来の損失導波構造と比べると, 実屈折率導波構造では 電流ブロック層での光吸収に起因する内部損失がほとん ど無視できるので, しきい值電流密度が低減でき, 低電流 動作 · 高温動作 ·高出力動作に適している10,11). また, 損失導波構造ではストライプ幅を変化させると電流分布 と光分布が同時に大きく変化するのに対し, 本構造では, ス トライプ幅を固定して電流分布を決定した上で, 電流ブ ロック層と埋め込みクラッド層の屈折率を変えることに より光分布のみを独立に制御することが可能となる4).こ のことにより,構造設計の自由度を飛躍的に高めることが できる，例えば, 電流分布を狭くし光分布を広くすること により, いわゆる自励発振型レーザーの設計マージンを大 きくすることが可能である5,12).

\section{2 モノリシック2波長レーザーへの適用}

Fig. 2に今回作製した実屈折率導波型モノリシック2波長 レーザーの基本構造を示す3). GaAs基板上に, $\mathrm{AlGaAs}$ 系で 構成した780 nm帯赤外レーザーとAlGaInP系で構成した $650 \mathrm{~nm}$ 帯赤色レーザーとをモノリシックに形成してい る。両レーザーともに前述の実屈折率導波型レーザー構 造を採用した。

Fig. 2に示した実屈折率導波型モノリシック2波長レー ザーの作製プロセスは以下の通りである。まず第 1 の MOCVD工程でn-GaAs (001) 基板上に780 nm帯レーザーの $\mathrm{n}-\mathrm{AlGaAs}$ クラット層, $\mathrm{AlGaAs}$ 多重量子井戸活性層, p$\mathrm{AlGaAs}$ クラッド層 $(\mathrm{I}), \mathrm{n}-\mathrm{AlGaAs}$ 電流ブロック層を成長す る。次に, ウエットエッチングにより電流ストライプ(幅 $\left.W_{1}\right)$ を形成した後, 第2のMOCVD工程によりp-AlGaAsクラッ ド層 (II) とp-GaAsコンタクト層を順次形成する. 次に, 上記 $780 \mathrm{~nm}$ 帯レーザー構造の一部をn-GaAs基板までエッチン グにより除去した後, 第3のMOCVD工程により $650 \mathrm{~nm}$ 帯

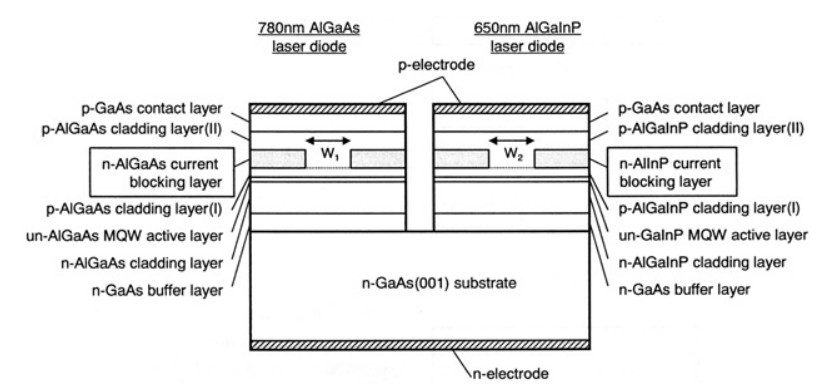

Fig. 2 Schematic drawing of monolithically-integrated dualwavelength laser diodes with real refractive indexguided self-aligned structure. 
レーザーのn-AlGaInPクラッド層, InGaP多重量子井戸活性 層, $\mathrm{p}-\mathrm{AlGaInP}$ クラッド層 $(\mathrm{I}), \mathrm{n}-\mathrm{AlInP}$ 電流ブロック層を形成 する. 次いで, ウエットエッチングにより電流ストライプ $\left(\right.$ 幅 $\left.W_{2}\right)$ を形成した上で, 第4のMOCVD工程により, pAlGaInPクラッド層 (II) とp-GaAsコンタクト層を順次形成 する。なお, p-AlGaInPクラッド層(II) は段差形状のストラ イプ上に再成長されることになるが,その際格子不整合に 起因する結晶欠陥の発生を抑止するように成長条件を選 択することが重要である13)。最後に両素子間にエッチン グにより溝 (分離溝) を形成した。な拉, 発光点間隔は 120 umとした。

素子特性を決定する上で重要なパラメータは, ストライ プ幅ならびに, 横方向の実効屈折率ステップであるが, こ れらはそれぞれの素子の目標特性に合わせて個別に設定 される。ただし，モノリシック2波長レーザーに扔いては， 両素子が共振器と端面を共有するという制約のもとで最 適設計を行う必要がある。

\section{3. 光ヘッド用実屈折率導波型モノリシック 2波長レーザー}

\section{1 再生用自励発振型2波長レーザー(低雑音化)}

通常の単一縦モード型半導体レーザーを光へッドに用 いる場合, 戻り光誘起雑音を低減するために一般に高周波 重畳回路が用いられる。この場合, $780 \mathrm{~nm}$ 帯レーザーと650 $\mathrm{nm}$ 帯レーザーでは電気的等価回路のインピーダンスが異 なるため, 最適な重畳特性を得るためにはそれぞれのレー ザーに適した2つの重畳回路を用いる必要が生じる場合も ある。このことは,光ヘッドの小型化・低コスト化を制約 する要因となっていた。これを解決するために, 自励発振 によって低雑音化が図られた 2 波長レーザーが求められて いる.

自励発振は, 電流ストライプ幅に対して光分布を水平方 向に十分広げることにより可飽和吸収体を活性層内部に 作り込むことによって発生させることが出来る ${ }^{14)}$ 。前述 のように, 実屈折率導波型構造ではストライプ幅で電流広 がりを決定した上で, 埋め込みクラッド層の屈折率を調整 することにより光分布を決定する $\Delta n$ を独立に制御できる ので, 自励発振を得るための設計マージンを大きく取るこ とができる6)。また, 高温まで安定した自励発振を維持す るためには, 電流密度を低減させキャリアのオーバーフ ローを抑制することが重要であるが, 電流ブロック層での 光吸収損失の無視できる実屈折率導波型構造は, この低電 流密度化にも適した構造である。このことは, 伝導帯のバ ンドオフセットがAlGaAs系と比べて小さいAlGaInP系赤色 半導体レーザーにおいて特に重要である。

本報告では $\Delta n$ の值を $780 \mathrm{~nm}$ 帯 $/ 650 \mathrm{~nm}$ 帯ともに3 $310^{-3}$ 台 に低減させ, 光分布を水平方向に広げた ${ }^{3)}$. 共振器長は500 $\mu \mathrm{m}$ とし, 反射率は出射面・裏面共に約 $30 \%$ とした。

Fig. 3に代表的な電流-光出力特性を示す. $780 \mathrm{~nm}$ 帯/650 $\mathrm{nm}$ 帯ともに $80^{\circ} \mathrm{C}$ まで安定した動作をしている。拡がり角 は780 nm帯レーザーが水平 $10.5^{\circ}$, 垂直 $33^{\circ}, 650 \mathrm{~nm}$ 帯レー ザーが水平 $12^{\circ}$, 垂直 $30^{\circ}$ である. Fig. 4 は直流駆動時 (平均

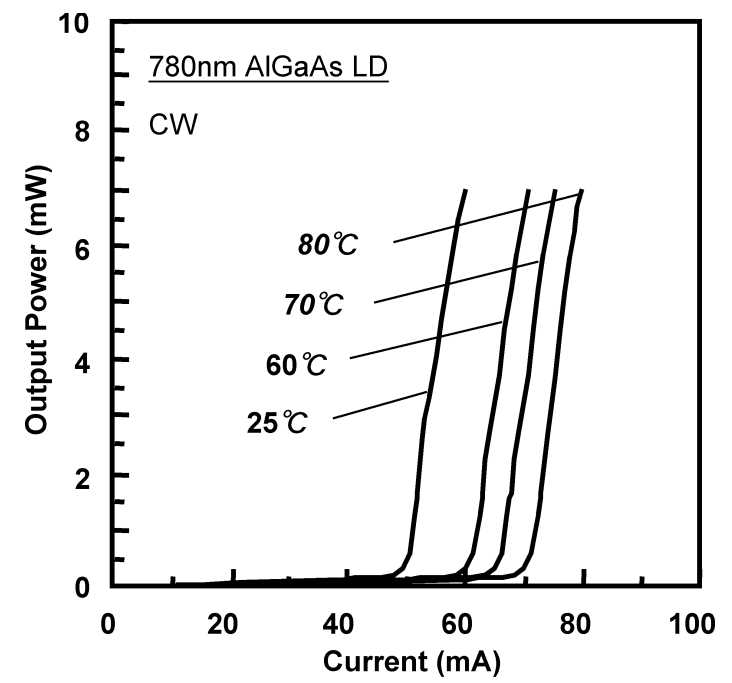

(a)

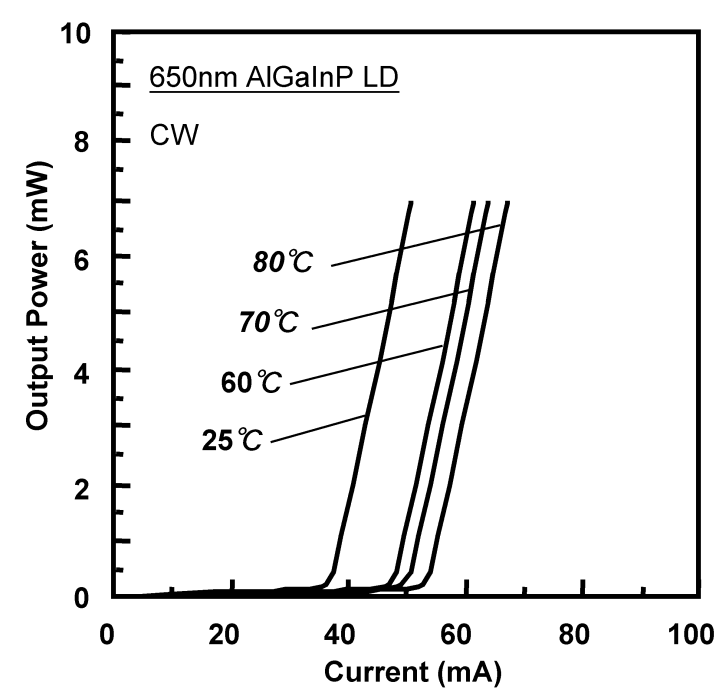

(b)

Fig. 3 Temperature dependence of L-I curves for (a) 780 nm-band AlGaAs and (b) 650 nm-band AlGaInP selfpulsating laser diodes, respectively.

光出力 $5 \mathrm{~mW}$ )の光出力時間変化を示したものである. とも に安定した自励発振が得られていることが分かる。また, Fig. 5に示すように相対雑音強度は780 nm带レーザーでは

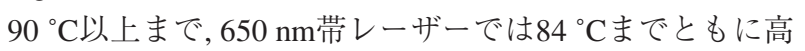
周波重畳なしで - $130 \mathrm{~dB} / \mathrm{Hz}$ 以下の良好なレベルを維持す ることが出来た.

\subsection{CD-R/RW記録対応2波長レーザー(高出力化)}

近年, $\mathrm{DVD}$ の再生機能と CD-R/RW記録・再生機能を兼ね 備えたドライブへの要望が高まりつつある。これを実現 するためには780 nm帯レーザー部の高出力化が必要とな る. 高出力化の最大のポイントは, 高出力動作時の空間的 ホールバーニングを抑制してキンクの発生を防止するこ とと, 端面光密度の低減により端面劣化を抑制することで ある. 共に精密な光分布制御が必要であり, 実屈折率導波 型構造の特徵を活かすことができる。 


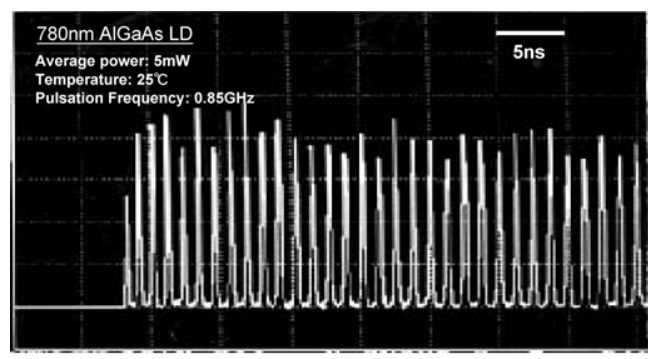

(a)

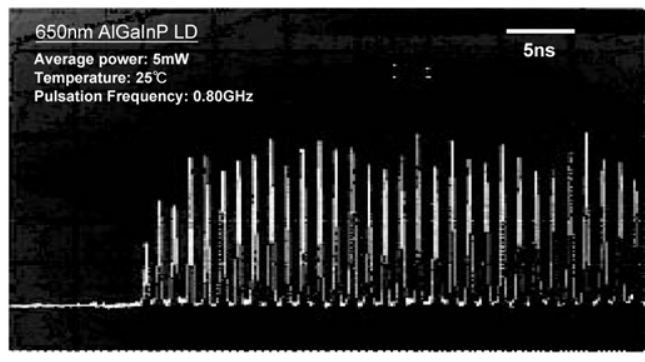

(b)

Fig. 4 Pulse trains of (a) $780 \mathrm{~nm}$-band AlGaAs and (b) 650 nm-band AlGaInP self-pulsating laser diodes, respectively. Each laser is operated at an average output power of $5 \mathrm{~mW}$ at $25^{\circ} \mathrm{C}$.

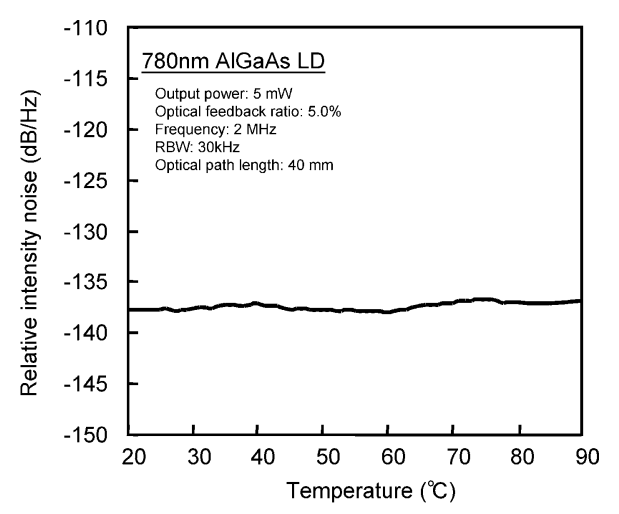

(a)

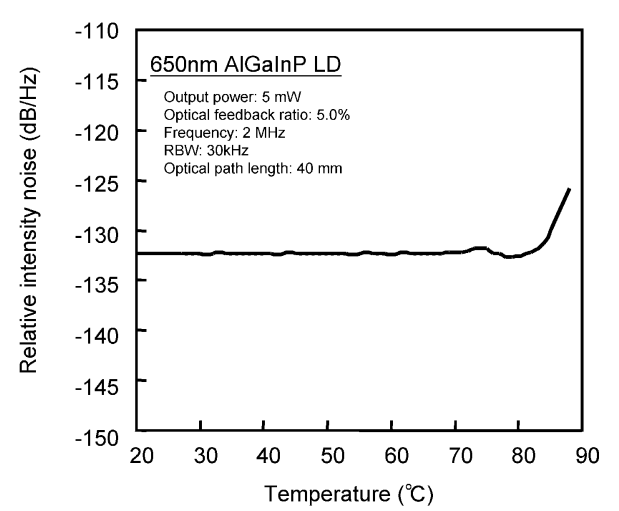

(b)

Fig. 5 Temperature dependence of relative intensity noise (RIN) for (a) $780 \mathrm{~nm}$-band AlGaAs and (b) $650 \mathrm{~nm}$ band AlGaInP self-pulsating laser diodes, respectively. Both lasers are operated at $5 \mathrm{~mW}$ with the optical feedback ratio of $5.0 \%$. Measurement frequency is $2 \mathrm{MHz}$ and resolution band width (RBW) is $30 \mathrm{KHz}$. Optical path length is $40 \mathrm{~mm}$.
作製したデバイスは, $\Delta n$ の值を780 nm帯については約4 × 10-3とした. $650 \mathrm{~nm}$ 帯レーザーについては, 低出力シン グルモード型としたので $\Delta n$ は約 $5 \times 10^{-3}$ とした. 共振器長 は800 $\mu \mathrm{m}$ とし, 端面反射率は $780 \mathrm{~nm}$ に対して出射面を $10 \%$, 董面を90\%とした。

Fig. 6に代表的な電流光出力特性を示す. 特に780 nm带

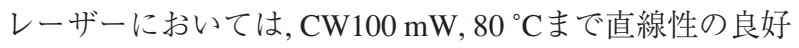
な特性を得ることが出来た ${ }^{15)}$ 。拡がり角は780 nm帯レー ザーが水平 $8.2^{\circ}$, 垂直 $17^{\circ}, 650 \mathrm{~nm}$ 帯レーザーが水平 9 。垂 直 27 である。また, Fig. 7に示すように, $780 \mathrm{~nm}$ 帯レーザー においては, $100 \mathrm{~mW} て ゙$ 安定した基本横モードが維持さ れており,空間的ホールバーニングが効果的に抑制されて いることが確認できた. Fig. 8はこのレーザーの信頼性評 価結果である。 $780 \mathrm{~nm}$ 帯レーザーは70 ${ }^{\circ} \mathrm{C}, 100 \mathrm{~mW}$ パルス 駆動 (パルス幅500 ns, 周期 $1 \mu \mathrm{s}$ ) にて, $650 \mathrm{~nm}$ 帯レーザーは 70 ㄷ, $7 \mathrm{~mW} \mathrm{CW}$ 駆動にてともに1000時間までの安定した 動作を確認できた。

\section{4. おわりに}

DVD/CD用光ヘッドの小型化・軽量化さらには低コスト 化に対応したモノリシック 2 波長半導体レーザーについて

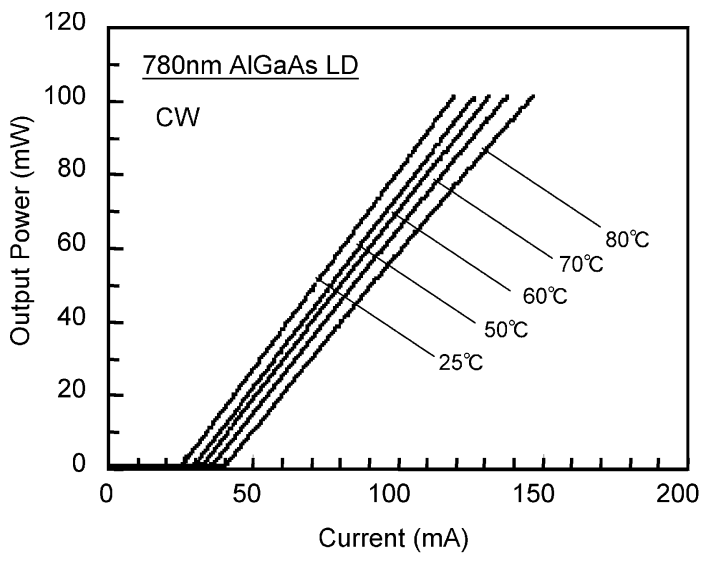

(a)

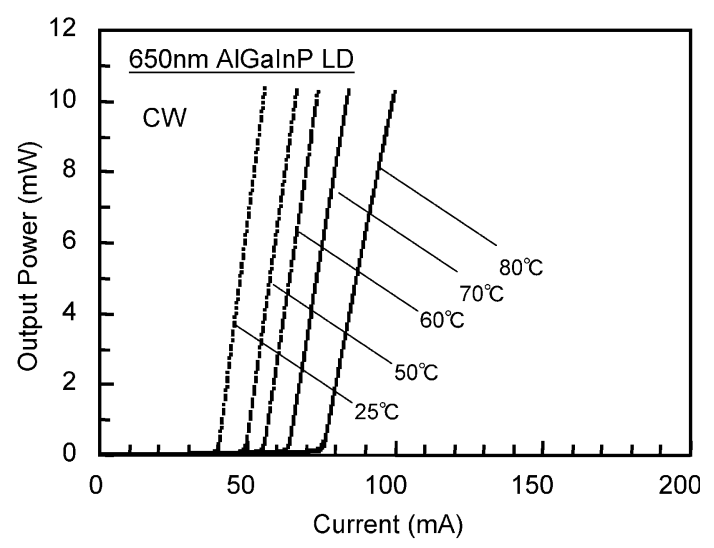

(b)

Fig. 6 Temperature dependence of L-I curves for (a) 780 nm-band high-power AlGaAs laser diode and (b) 650 nm-band low-power single-mode AlGaInP laser diode, respectively. 


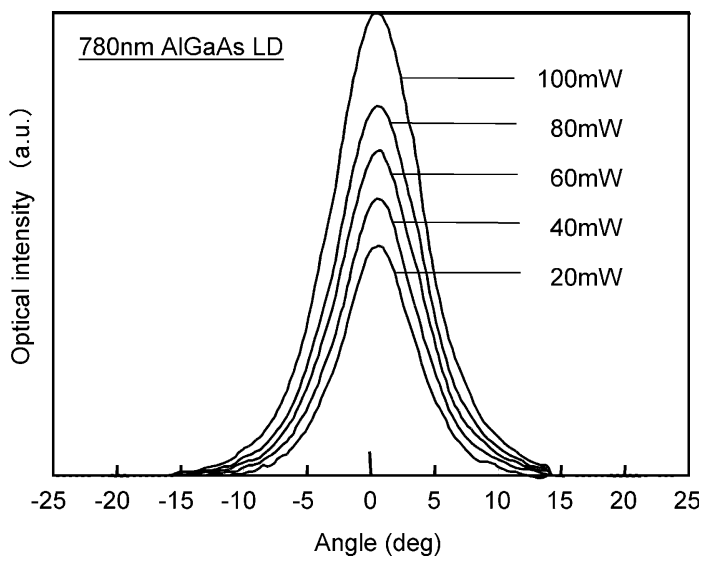

Fig. 7 Power dependence of far-field pattern in $780 \mathrm{~nm}$ band high-power AlGaAs laser diode.

説明した。

内部損失を低減してレーザー特性を向上させると共に 設計自由度を拡大するために, 基本構造として780 nm帯/ $650 \mathrm{~nm}$ 帯ともに実屈折率導波構造を採用した。これに よって, $780 \mathrm{~nm}$ 帯/650 nm帯ともに自励発振型レーザーと したモノリシック2波長レーザーを作製し, 高周波重畳回路 なしで $80^{\circ} \mathrm{C}$ 以上までの低雑音特性を確認した。さらには, 高出力780 nm帯レーザーを搭載したCD-R/RW記録対応モ

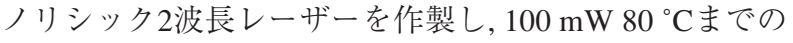
安定した動作と良好な信頼性を実現することができた。

\section{参考文献}

1) 塩澤 秀夫, 岡田 真琴, 渡邊 実, 伊藤 義行, 田中 明, 河本 聡, 角田和哉, 飯田 清次, 玄永 康一, 島田 直弘, 奥田 肇, 内崎一郎, 福岡 和雄：電子通信情報学会 信学技報 ED99-197 CPM99-108 (1999) p. 41.

2) 根本 和彦, 美濃野靖, 山田 雄次, 成井 啓修, 桶口 慶信, 亀井 正文, 今西大介, 岩本 浩治, 平田 照二 : 第60回応用物理学会 学術講演会 (1999年秋) 3a-Zc-10.

3) 小林康宏, 今藤修, 大西俊一, 福久敏哉, 油利 正昭, 伊藤 国雄：第47回応用物理学関係連合講演会予稿集 (2000年春) $29 \mathrm{a}-\mathrm{N}-4$.

4) 河本 聡, 塩澤 秀夫, 岡田 真琴, 渡邊 実, 伊藤 義行, 田中 明, 角田和哉, 飯田 清次, 玄永康一, 島田 直弘, 奥田 肇, 内崎一郎, 福岡和雄: 第47回応用物理学関係連合講演会 (2000年春) $29 \mathrm{a}-$ $\mathrm{N}-5$.

5) T. Ohnisi, O. Imafuji, T. Fukuhisa, A. Mochida, Y. Kobayashi, M. Yuri, and K. Itoh: Technical Digest of the 5th Optoelectronics and Communications Conference (OECC 2000) (2000) 532 14C2-3.

6) 油利 正昭, 今藤修, 高山徹：レーザー研究 25 (1997) 547.

7) J. J. Coleman and P. D. Dapkus: Appl. Phys. Lett. 37 (1980) 262.

8) O. Imafuji,T. Takayama, H. Sugiura, M. Yuri, H. Naito, M. Kume, and K. Itoh: IEEE J. Quantum Electron. QE-29 (1993) 1889.

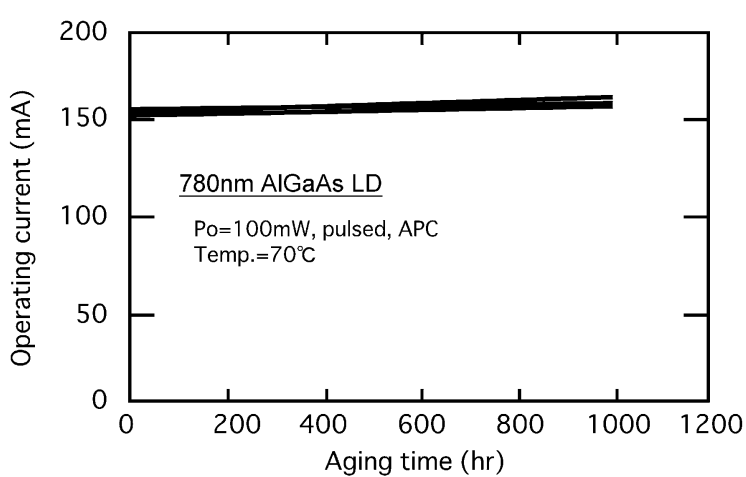

(a)

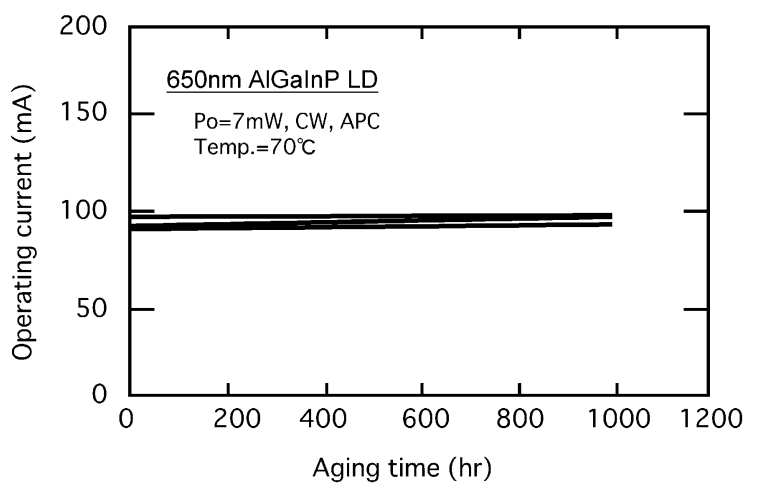

(b)

Fig. 8 Aging test results of (a) $780 \mathrm{~nm}$-band high-power AlGaAs laser diode operated at $100 \mathrm{~mW} / 70{ }^{\circ} \mathrm{C}$ under pulsed condition (pulse width is $500 \mathrm{nsec}$ and period is $1 \mu \mathrm{sec}$ ) and (b) $650 \mathrm{~nm}$-band low-power single-mode $\mathrm{AlGaInP}$ laser diode operated at $7 \mathrm{~mW} /$ $70{ }^{\circ} \mathrm{C}$ under $\mathrm{CW}$ condition, respectively.

9) O. Imafuji, T. Fukuhisa, M. Yuri, M. Mannoh, A. Yoshikawa, and K. Itoh: IEEE J. Selected Topics Quantum Electron. 15 (1999) 721.

10) T. Ohnishi, O. Imafuji, T. Fukuhisa, Y. Kobayashi, M. Yuri, M. Mannoh, A. Yoshikawa, and K. Itoh: Electron. Lett. 35 (1999) 2208.

11) O. Imafuji, M. Yuri, T. Hashimoto, M. Ishida, M. Mannoh, T. Kawata, H. Ogawa, A. Yoshikawa, and K. Itoh: Electron. Lett. 33 (1997) 1223.

12) T. Takayama, O. Imafuji, T. Hashimoto, M. Yuri, A. Yoshikawa, and K. Itoh: Appl. Phys. Lett. 69 (1996) 3656.

13) T. Fukuhisa, O. Imafuji, M. Mannoh, M. Yuri, and K. Itoh: J. Crystal Growth 221 (2000) 208.

14) M. Yuri, J. S. Harris, Jr., T. Takayama, O. Imafuji, H. Naito, M. Kume, K. Itoh, and T. Baba: IEEE J. Selected Topics Quantum Electron. 1 (1995) 473.

15) 持田 篤範, 大西 俊一, 小林康宏, 福久敏哉, 今藤修, 油利 正昭, 伊藤 国雄：第61回応用物理学会学術講演会 (2000年秋) 6a-R6.

\section{2波長レーザー (dual-wavelength laser diode)}

波長の異なる 2 種類のレーザー光を個別に出射すること のできる半導体レーザー．2つの発光部が同一材料系から なり比較的小さい波長差 (数 $\mathrm{nm}$ ) を有する夕イプと, 異な る材料系で構成され大きな波長差(百 $\mathrm{nm}$ 以上) を有する夕 イプとがある。近年, 特に後者のタイプにおいて, AlGaInP
系の赤色発光部 (約650 $\mathrm{nm}$ ) と $\mathrm{AlGaAs}$ 系の赤外発光部(約 $780 \mathrm{~nm}$ ) 集積化した2波長レーザーの開発が盛んに行われ ており,これを用いることにより, 従来赤色, 赤外 $2 つ の$ 個 別半導体レーザーを用いていたDVD/CD互換ピックアップ を大幅に小型化, 簡素化することができる。（油利 正昭） 